\title{
25 Research Square \\ Future climate and land use instability can negate the benefits of protected areas
}

\author{
Ernest Asamoah ( $\nabla$ asamfrt@gmail.com ) \\ Macquarie University https://orcid.org/0000-0003-0712-5642 \\ Linda Beaumont \\ Macquarie University \\ Joesph M Maina \\ Macquarie University
}

Article

Keywords: biodiversity, protected areas (PAs), sustainable development

Posted Date: March 30th, 2021

DOl: https://doi.org/10.21203/rs.3.rs-270966/v1

License: (1) This work is licensed under a Creative Commons Attribution 4.0 International License.

Read Full License

Version of Record: A version of this preprint was published at Nature Climate Change on November 25th, 2021. See the published version at https://doi.org/10.1038/s41558-021-01223-2. 


\section{Abstract}

Expanding protected area networks and enhancing their capacities is currently one avenue at the forefront of efforts to conserve and restore global biodiversity. Climate and habitat loss resulting from land use interact synergistically to undermine the potential benefits of protected areas (PAs). Targeting conservation, adaptation and mitigation efforts requires an understanding of patterns of climate and land-use change within the current arrangement of PAs, and how these might change in the future. In this paper, we provide this understanding using predicted rates of temporal and spatial displacement of future climate and land use globally and within PAs. We show that $~ 47 \%$ of the world's PAs $-10.6 \%$ of which are under restrictive management-are located in regions that will likely experience both climate stress and land-use instability by 2050 . The vast majority of these PAs are also distributed across moist biomes and in high conservation value regions, and fall into less-restrictive management categories. The differential impacts of combined land use and climate velocity across protected biomes indicate that climate and land-use change may have fundamentally different ecological and management consequences at multiple scales. Taken together, our findings can inform spatially adaptive natural resource management and actions to achieve sustainable development and biodiversity goals.

\section{Introduction}

Protected areas are a fundamental tool for protecting Earth's biodiversity from excessive rates of extinction and erosion of goods and services ${ }^{1,2}$. However, the efficacy of PAs is expected to decline, given that climate conditions available for species within spatially static PAs will alter as climate change intensifies. ${ }^{3-5}$ Moreover, habitat loss and fragmentation resulting from human activities may cause a structural disconnection across PA networks that impedes the ability of species to undergo range shifts and track their climate envelope. ${ }^{6-9}$ Assessing the potential for the biodiversity contained within PAs to respond to the combined impacts of these stressors is crucial to developing adaptive management approaches to conservation. ${ }^{10,11}$

In this paper, we examine spatiotemporal changes in climate and land use across biomes and within PAs globally. Using regionally downscaled temperature and precipitation data from the Coordinated Regional Climate Downscaling Experiment (CORDEX) ${ }^{12}$ and moderate-resolution land-use states from the Harmonized Global Land Use [LUH2 v2f] ${ }^{13}$ we present climate and land-use changes as a velocity (km yr ${ }^{-1}$ ) -the ratio of temporal trends $\left({ }^{\circ} \mathrm{C} \mathrm{yr}^{-1}\right.$ or $\left.\% \mathrm{yr}^{-1}\right)$ to the spatial gradient $\left({ }^{\circ} \mathrm{C} \mathrm{km}^{-1}\right.$ or $\left.\% \mathrm{~km}^{-1}\right)$. For both of these stressors, we consider estimates based on the Representative Concentration Pathways (RCP) 8.5 or Shared Socioeconomic Pathway (SSP) 5 and RCP 2.6 or SSP1, which we refer to hereafter as business as usual (BAU) and mitigation scenarios respectively.

Climate velocity is a useful surrogate for the potential movement requirements of species over time, as conditions across their range become less similar to the baseline epoch. ${ }^{14}$ Likewise, land-use velocity (hereafter termed land-use instability) represents changes in the composition of land use across a 
spatially varying gradient. ${ }^{15}$ We examine and compare climate velocity and land-use instability for the near future (2015-2050) and far future (2065-2100) relative to the baseline of 1971-2005. Changes during the near-future epoch are particularly important as they may influence achievement of the 2030 targets for sustainable development ${ }^{16}$ and the Convention on Biological Diversity's 2050 biodiversity vision of 'living in harmony with nature'. ${ }^{17}$ From this perspective, we examine correlations between climate velocity, land-use instability and characteristics of PAs such as tetrapod richness (i.e., the richness of birds, mammals, reptiles and amphibians) and PA location (i.e., Euclidean distance from the ocean and elevation). We also examine differences in exposure of PAs under different management restrictions. Relating expected changes in environmental conditions within PAs can inform decisions to remove, shrink or relax PAs to accommodate ecologically dynamic conservation objectives. ${ }^{18}$

We find that the predicted velocity at which a species may be required to track its climate envelope during the near-future epoch averages $3.93 \pm 3.66 \mathrm{~km} \mathrm{yr}^{-1}$ under the mitigation scenario [mean \pm standard deviation] (Table S1), and increases to $5.97 \pm 5.01 \mathrm{~km} \mathrm{yr}^{-1}$ under the BAU scenario. Further, there is a strong positive correlation between climate velocity computed for BAU and mitigation scenarios (bivariate regression: $R^{2}=0.85$, Extended Data, Fig. $1 \mathrm{a}$ and $\mathrm{c}$ ). This also suggests that the potential effect of climate mitigation on species is strongly additive, and that most of Earth's terrestrial regions are likely to experience a similar pattern of horizontal movement of climate under both BAU and mitigation scenarios, although the magnitude of velocity varies across biomes (Extended Data, Fig. 1b). Given that the current global warming trajectory is tracking RCP $8.5,{ }^{19}$ we focus on the dynamics predicted under the BAU scenario.

Patterns of climate velocity and land-use instability in protected areas. Within PAs, climate velocity averaged $4.07 \pm 4.52 \mathrm{~km} \mathrm{yr}^{-1}$ during the baseline epoch (1971-2005), which is similar to the global mean $\left(4.24 \pm 4.13 \mathrm{~km} \mathrm{yr}^{-1}\right.$, Table 1) but increases to $5.76 \pm 5.41 \mathrm{~km} / \mathrm{yr}$ in the near future. As the century progresses, velocity is projected to increase five-fold to an average speed of $21.06 \pm 20.18 \mathrm{~km} \mathrm{yr}^{-1}$ across PAs during the far-future epoch. While velocity is consistently slowest in montane grasslands and shrublands, and coniferous forests, average rates in excess of $20 \mathrm{~km} \mathrm{yr}^{-1}$ are projected across six biomes by the far future, reaching up to $42.65 \mathrm{~km} \mathrm{yr}^{-1}$ in flooded grasslands and savannahs (Table 1).

Overall, in both future epochs temperature velocity is higher than that of precipitation, with a mean difference of $\sim 1.99$ and $\sim 15.25 \mathrm{~km} \mathrm{yr}^{-1}$ respectively (Table S1). These differences are predictable because the changes in precipitation over time tend to be lower compared to the spatial gradients (Table S1). Moreover, both climate variables are weakly positively correlated (Spearman rho $|\rho|=0.51, P<$ $0.001)$, suggesting spatial congruence in temperature and precipitation velocities.

We assess the effects of cumulative human pressure on the velocity at which species may be required to track suitable climate envelopes. To achieve this, we calculated land-use instability, with constraints on ten land-use facets predicted under SSP5 (Methods). In contrast to climate velocity, as the twenty-first century progresses, land-use instability is predicted to decline under SSP5 (Fig. 1, Extended Data, Fig. 3). 
Instability for the near future averaged $2.03 \pm 4.62 \mathrm{~km} \mathrm{yr}^{-1}$ across PAs, a decline of $\sim 42 \%$ from the $1971-2005$ baseline $\left(3.49 \pm 9.36 \mathrm{~km} \mathrm{yr}^{-1}\right)$, with values across biomes ranging between 0.22 and $3.94 \mathrm{~km}$ $\mathrm{yr}^{-1}$ (Table 1). Across the near future, land-use instability is projected to be highest in protected tropical moist forests and tropical grassland and savannahs, and lowest in temperate, and desert and xeric biomes. By the century's end, however, instability is likely to be greatest in taiga and boreal forests $(1.50 \pm$ $\left.4.64 \mathrm{~km} \mathrm{yr}^{-1}\right)$, although still considerably slower than previous epochs. The declining land-use instability may be due to the loss of vegetation integrity. Moreover, by mid- to late century, much of the land-use transition from natural to human-modified forms with low transition potential will have already occurred, thus reducing the probability of spatial displacement of land use relative to small temporal trends in the future.

Effect of management on climate and land-use changes. Across all epochs, the values of climate velocity and land-use instability for non-protected areas show similar patterns to those for PAs, indicating that, if changes continue unabated, PAs may fail to achieve global biodiversity conservation goals. We found PAs within the more restrictive management categories (IUCN categories I-II) to have significantly slower climate velocity (Welch $t=-18.68, P<0.001$ ) and lower land-use instability (Welch $t=-23.34, P<0.001$ ) compared to other classifications (NAV) (Extended Data, Fig. 5). 
Table 1

Summary of climate velocity and land-use instability within biomes and protected areas (PAs). Estimates for the near-future (2015-2050) and far-future (2065-2100) epochs are based on the BAU scenario (Representative Concentration Pathway (RCP) 8.5) and Shared Socioeconomic Pathway (SSP) 8.5. Abbreviations: PAs refer to their International Union for Conservation of Nature (IUCN) management category: I-II have stricter conservation management objectives; NAV either have objectives that are less strict, not categorised by IUCN, or their status is depicted as 'not available' in the World Database on Protected Areas (WPDA) datasets.

\begin{tabular}{|c|c|c|c|c|c|c|}
\hline & \multicolumn{3}{|c|}{ Climate velocity $\left(\mathrm{km} \mathrm{yr}^{-1}\right)$} & \multicolumn{3}{|c|}{$\begin{array}{l}\text { Land-use instability (km yr } \\
\text { 1) }\end{array}$} \\
\hline & $\begin{array}{l}1971- \\
2005\end{array}$ & $\begin{array}{l}2015- \\
2050\end{array}$ & $\begin{array}{l}2065- \\
2100\end{array}$ & $\begin{array}{l}1971- \\
2005\end{array}$ & $\begin{array}{l}2015- \\
2050\end{array}$ & $\begin{array}{l}2065- \\
2100\end{array}$ \\
\hline Global mean & $\begin{array}{l}4.24 \pm \\
4.13\end{array}$ & $\begin{array}{l}6.01 \pm \\
5.02\end{array}$ & $\begin{array}{l}21.05 \pm \\
20.18\end{array}$ & $\begin{array}{l}6.34 \pm \\
14.58\end{array}$ & $\begin{array}{l}1.56 \pm \\
4.02\end{array}$ & $\begin{array}{l}0.82 \pm \\
2.62\end{array}$ \\
\hline Within protected areas & $\begin{array}{l}4.07 \pm \\
4.52\end{array}$ & $\begin{array}{l}5.76 \pm \\
5.41\end{array}$ & $\begin{array}{l}21.36 \pm \\
23.13\end{array}$ & $\begin{array}{l}3.49 \pm \\
9.36\end{array}$ & $\begin{array}{l}2.03 \pm \\
4.62\end{array}$ & $\begin{array}{l}0.75 \pm \\
2.57\end{array}$ \\
\hline$\cdot \mid-11$ & $\begin{array}{l}3.48 \pm \\
4.06\end{array}$ & $\begin{array}{l}5.10 \pm \\
5.04\end{array}$ & $\begin{array}{l}19.19 \pm \\
22.0\end{array}$ & $\begin{array}{l}9.32 \pm \\
9.41\end{array}$ & $\begin{array}{l}1.63 \pm \\
3.82\end{array}$ & $\begin{array}{l}0.75 \pm \\
2.84\end{array}$ \\
\hline - NAV & $\begin{array}{l}4.33 \pm \\
4.67\end{array}$ & $\begin{array}{l}6.05 \pm \\
5.54\end{array}$ & $\begin{array}{l}22.30 \pm \\
23.54\end{array}$ & $\begin{array}{l}3.73 \pm \\
9.32\end{array}$ & $\begin{array}{l}2.20 \pm \\
4.91\end{array}$ & $\begin{array}{l}0.75 \pm \\
2.45\end{array}$ \\
\hline Outside protected areas & $\begin{array}{l}4.26 \pm \\
4.07\end{array}$ & $\begin{array}{l}6.05 \pm \\
4.96\end{array}$ & $\begin{array}{l}21.00 \pm \\
19.70\end{array}$ & $\begin{array}{l}6.76 \pm \\
15.16\end{array}$ & $\begin{array}{l}1.50 \pm \\
3.92\end{array}$ & $\begin{array}{l}0.83 \pm \\
2.63\end{array}$ \\
\hline \multicolumn{7}{|l|}{ Protected biomes } \\
\hline Deserts and xeric shrublands & $\begin{array}{l}5.23 \pm \\
5.23\end{array}$ & $\begin{array}{l}7.09 \pm \\
5.60\end{array}$ & $\begin{array}{l}20.44 \pm \\
18.05\end{array}$ & $\begin{array}{l}2.47 \pm \\
11.40\end{array}$ & $\begin{array}{l}0.19 \pm \\
0.65\end{array}$ & $\begin{array}{l}0.03 \pm \\
0.19\end{array}$ \\
\hline $\begin{array}{l}\text { Flooded grasslands and } \\
\text { savannas }\end{array}$ & $\begin{array}{l}5.75 \pm \\
3.95\end{array}$ & $\begin{array}{l}10.25 \\
\pm 8.84\end{array}$ & $\begin{array}{l}42.65 \pm \\
47.14\end{array}$ & $\begin{array}{l}3.43 \pm \\
7.28\end{array}$ & $\begin{array}{l}1.90 \pm \\
4.57\end{array}$ & $\begin{array}{l}0.58 \pm \\
1.96\end{array}$ \\
\hline Mangroves & $\begin{array}{l}2.19 \pm \\
1.91\end{array}$ & $\begin{array}{l}3.04 \pm \\
1.47\end{array}$ & $\begin{array}{l}11.48 \pm \\
7.02\end{array}$ & $\begin{array}{l}5.42 \pm \\
12.81\end{array}$ & $\begin{array}{l}2.45 \pm \\
3.43\end{array}$ & $\begin{array}{l}0.76 \pm \\
1.96\end{array}$ \\
\hline $\begin{array}{l}\text { Mediterranean forests, } \\
\text { woodlands and scrub }\end{array}$ & $\begin{array}{l}1.81 \pm \\
3.33\end{array}$ & $\begin{array}{l}3.62 \pm \\
3.56\end{array}$ & $\begin{array}{l}9.30 \pm \\
8.28\end{array}$ & $\begin{array}{l}3.44 \pm \\
8.53\end{array}$ & $\begin{array}{l}0.60 \pm \\
1.27\end{array}$ & $\begin{array}{l}0.26 \pm \\
0.52\end{array}$ \\
\hline $\begin{array}{l}\text { Montane grasslands and } \\
\text { shrublands }\end{array}$ & $\begin{array}{l}0.84 \pm \\
0.86\end{array}$ & $\begin{array}{l}1.20 \pm \\
0.97\end{array}$ & $\begin{array}{l}4.12 \pm \\
4.27\end{array}$ & $\begin{array}{l}5.11 \pm \\
10.42\end{array}$ & $\begin{array}{l}1.63 \pm \\
3.59\end{array}$ & $\begin{array}{l}0.58 \pm \\
2.02\end{array}$ \\
\hline Taiga and boreal forests & $\begin{array}{l}4.63 \pm \\
4.37\end{array}$ & $\begin{array}{l}6.54 \pm \\
4.86\end{array}$ & $\begin{array}{l}24.94 \pm \\
21.16\end{array}$ & $\begin{array}{l}2.24 \pm \\
7.73\end{array}$ & $\begin{array}{l}1.98 \pm \\
5.11\end{array}$ & $\begin{array}{l}1.50 \pm \\
4.64\end{array}$ \\
\hline Temperate coniferous forests & $\begin{array}{l}0.92 \pm \\
1.48\end{array}$ & $\begin{array}{l}1.38 \pm \\
1.30\end{array}$ & $\begin{array}{l}4.58 \pm \\
4.50\end{array}$ & $\begin{array}{l}5.61 \pm \\
13.12\end{array}$ & $\begin{array}{l}1.21 \pm \\
2.34\end{array}$ & $\begin{array}{l}0.79 \pm \\
2.04\end{array}$ \\
\hline $\begin{array}{l}\text { Temperate grasslands, savannas } \\
\text { and shrublands }\end{array}$ & $\begin{array}{l}3.28 \pm \\
2.59\end{array}$ & $\begin{array}{l}4.85 \pm \\
3.60\end{array}$ & $\begin{array}{l}15.77 \pm \\
12.84\end{array}$ & $\begin{array}{l}4.15 \pm \\
9.65\end{array}$ & $\begin{array}{l}0.22 \pm \\
0.84\end{array}$ & $\begin{array}{l}0.32 \pm \\
0.76\end{array}$ \\
\hline Temperate mixed forests & $\begin{array}{l}3.61 \pm \\
4.18\end{array}$ & $\begin{array}{l}3.60 \pm \\
3.34\end{array}$ & $\begin{array}{l}13.98 \pm \\
13.20\end{array}$ & $\begin{array}{l}5.23 \pm \\
8.99\end{array}$ & $\begin{array}{l}1.20 \pm \\
2.37\end{array}$ & $\begin{array}{l}0.51 \pm \\
1.36\end{array}$ \\
\hline
\end{tabular}




\begin{tabular}{|c|c|c|c|c|c|c|}
\hline & \multicolumn{3}{|c|}{ Climate velocity ( $\left.\mathrm{km} \mathrm{yr}^{-1}\right)$} & \multicolumn{3}{|c|}{$\begin{array}{l}\text { Land-use instability (km yr } \\
1 \text { ) }\end{array}$} \\
\hline & $\begin{array}{l}1971- \\
2005\end{array}$ & $\begin{array}{l}2015- \\
2050\end{array}$ & $\begin{array}{l}2065- \\
2100\end{array}$ & $\begin{array}{l}1971- \\
2005\end{array}$ & $\begin{array}{l}2015- \\
2050\end{array}$ & $\begin{array}{l}2065- \\
2100\end{array}$ \\
\hline Tropical coniferous forests & $\begin{array}{l}1.12 \pm \\
0.80\end{array}$ & $\begin{array}{l}1.52 \pm \\
0.84\end{array}$ & $\begin{array}{l}4.91 \pm \\
3.01\end{array}$ & $\begin{array}{l}4.88 \pm \\
11.46\end{array}$ & $\begin{array}{l}1.63 \pm \\
2.98\end{array}$ & $\begin{array}{l}0.54 \pm \\
1.56\end{array}$ \\
\hline Tropical dry forests & $\begin{array}{l}3.57 \pm \\
3.58\end{array}$ & $\begin{array}{l}4.56 \pm \\
3.44\end{array}$ & $\begin{array}{l}19.84 \pm \\
18.36\end{array}$ & $\begin{array}{l}5.36 \pm \\
9.97\end{array}$ & $\begin{array}{l}1.73 \pm \\
2.98\end{array}$ & $\begin{array}{l}0.79 \pm \\
1.77\end{array}$ \\
\hline $\begin{array}{l}\text { Tropical grasslands, savannas } \\
\text { and shrublands }\end{array}$ & $\begin{array}{l}4.10 \pm \\
4.46\end{array}$ & $\begin{array}{l}6.29 \pm \\
5.83\end{array}$ & $\begin{array}{l}24.47 \pm \\
26.88\end{array}$ & $\begin{array}{l}4.47 \pm \\
8.93\end{array}$ & $\begin{array}{l}3.86 \pm \\
6.52\end{array}$ & $\begin{array}{l}0.70 \pm \\
1.86\end{array}$ \\
\hline Tropical moist forests & $\begin{array}{l}4.25 \pm \\
4.16\end{array}$ & $\begin{array}{l}6.55 \pm \\
5.66\end{array}$ & $\begin{array}{l}27.26 \pm \\
25.72\end{array}$ & $\begin{array}{l}4.00 \pm \\
9.36\end{array}$ & $\begin{array}{l}3.94 \pm \\
5.77\end{array}$ & $\begin{array}{l}1.06 \pm \\
2.27\end{array}$ \\
\hline Tundra & $\begin{array}{l}5.43 \pm \\
5.84\end{array}$ & $\begin{array}{l}7.04 \pm \\
6.26\end{array}$ & $\begin{array}{l}27.05 \pm \\
28.54\end{array}$ & $\begin{array}{l}0.22 \pm \\
1.61\end{array}$ & $\begin{array}{l}0.53 \pm \\
2.94\end{array}$ & $\begin{array}{l}0.79 \pm \\
3.69\end{array}$ \\
\hline
\end{tabular}

\section{Climate change and land-use instability interact to offset conservation goals}

A bivariate exposure space bounded by land use (x-axis) and climate (y-axis) highlights opportunities for adaptation and conservation prioritisation globally (Fig. 2a). The intersection of the bivariate velocity space with PA locations suggests that the current arrangement of PAs and the spread across the exposure space represents a diversified portfolio, which can reduce environmental change-related conservation uncertainty. ${ }^{21}$ However, $\sim 71 \%$ of PAs are poised to experience high climate stress by 2050 (Fig. 2b, quadrants TL and TR). The majority of these PAs (47\%) fall within regions where land-use instability is also high, suggesting that the current global investment in biodiversity conservation hedges towards high-risk zones in the near future. Locations of these PAs are concentrated in western and central Africa, northern North America, Amazonian South America, and Southeast Asia (Fig. 2a). A significantly lower proportion of PAs (4.7\%) is likely to be exposed to moderate climate velocity and land-use instability (Fig. 2b, quadrant BL). These PAs are spread across montane regions of Eastern North America, Southeast Asia and South America. In contrast, 20\% of PAs are located in regions where the velocity of expanding analogous climate may likely control environmental change within PAs relative to low land-use instability.

To explore these exposure spaces within the global conservation and sustainable development discourse, we examined correlations (using $t$-test modified for spatial autocorrelations ${ }^{20}$ ) of projected velocity and instability during the near future to key attributes of PAs-their management categories, location 
(elevation and distance from coasts) and tetrapod richness (richness of birds, mammals, reptiles and amphibians). We find that the PAs with the fastest climate velocities were located in close proximity to coasts and on relatively flat landscapes (Extended Data, Table 1), suggesting species in coastal regions will need to move rapidly towards currently cooler regions to track their climate envelope, ${ }^{22}$ with minimal topographical impediment to migration. ${ }^{23}$ However, in contrast to climate, land-use instability across PAs generally increases rapidly towards the coast, indicating that coastal development is likely to impede climate-driven range shifts in the near future. We also found a weak positive association between climate velocity and tetrapod richness, which markedly differed by biome, suggesting fundamentally different ecological and management consequences at multiple scales. Other reporting has suggested that PAs that are very important for conserving Red List species may be less affected by novel climate conditions until 2070 than relatively less important PAs. ${ }^{4}$

\section{Ecological And Policy Implications}

Our results indicate that $\sim 29 \%$ (quadrants BL $+B R$, Fig. $2 b$ ) of PAs will likely experience low climate stress by the mid-twenty-first century. Low-velocity regions may coincide with those where local climate conditions are less likely to shift. ${ }^{24}$ Conversely, the relative likelihood that species assemblages will disaggregate in these areas may be low, ${ }^{25}$ and the slower velocity may facilitate biological responses such as migration or adaptive evolutionary change. ${ }^{25-27}$ Worryingly, most of these PAs ( 24\%) are located in regions were land-use instability may be high, suggesting that land-use change may undermine putative climate refugia for species throughout eastern Europe, Scandinavia, eastern North America, southeast Asia and eastern Africa (Fig. 2a, Extended Data, Fig. 2a-c). Human-mediated reduction in vegetation integrity and structural connectivity often coincides with regions where climate stability may support species niche conservatism. ${ }^{10}$ Therefore, localised land-use actions-such as expanding reserve systems, enhancing and protecting elevational gradients, and intensive management-will likely benefit biodiversity and ecosystem services, in addition to global efforts to stabilise temperatures at or below 2 ${ }^{\circ} \mathrm{C} .28-30$

Prioritisation of protection, restoration, and connectivity for PAs in those regions where our results suggest that the velocity of climate change will be may benefit some species by facilitating their connection to areas with analogous climate. However, given that for many species the velocity of change is likely to far exceed their dispersal capabilities, ${ }^{22}$ other actions (including intensive management and the more controversial idea of managed translocation ${ }^{28-30}$ ) to promote tolerance or adaptation to climate change may be vital to their survival. To contextual this in terms of policy, the restoration of about 350 million hectares of degraded land by 2030, as per the UN declaration of 'a Decade on Ecosystem Restoration', will likely benefit regions exposed to slow climate velocity and high land-use instability, such as the African Sahel, western North America, southern Latin America and northwest Asia. Therefore, it is important that policymakers define desired outcomes clearly and spatially target interventions accordingly. Initiatives aimed at establishing corridors would benefit from incorporating species- and biome-specific information to accommodate the marked discrepancies in land use and climate change 
across biomes. ${ }^{31}$ Conversely, efforts to enhance adaptation will be required for most regions, such as the eastern USA and European Union, where climate change will likely be the dominant driver of environmental change towards 2100 .

Moreover, the fact that most PAs (47\%) are positioned in regions predicted to experience high climate velocity and high land-use instability reinforce previous reports indicating that if change continues unabated, species' dispersal and survival may lag behind a highly unstable climate environment. ${ }^{14,22,32,33}$ Rapid changes to the use of landscapes may further impede the ability of species to spatially track movements of their climate niche, ${ }^{15,25,27}$ increasing extinction risks ${ }^{34,35}$-with resident species with low dispersal abilities being most vulnerable. These findings support the current view that future land-use change will compound climate stress, thereby seriously challenging global conservation goals. $3,7,36$ While this may be the case, several evolving initiatives are looking beyond 2020. For example, the post-2020 framework of the Convention on Biological Diversity looks to embrace the 'reducing threats' goals of previous frameworks. To fully capture these goals, targets must be ambitious and measurable across all aspects of what makes PAs effective. ${ }^{36}$ Additionally, there is a need for explicit integration of climate adaptation principles into PA distribution and objectives to maintain network effectiveness as climate and land use change. ${ }^{37}$

In this study, we harness the moderate-resolution CORDEX and LUH2 vf datasets to develop a metric at a global scale representing the speed at which species must migrate to keep pace with a shifting climate and the degree of land-use (in)stability they may face. However, there are important caveats to our approach. First, we focused on PAs with a size that equals the resolution of CORDEX $\left(\sim 0.22^{\circ}, \sim 24.2 \mathrm{~km}\right.$ at the Equator). This approach effectively ignores the velocity and instabilities within small PAs which are needed to meet local biodiversity goals. ${ }^{18}$ Additionally, our definition of biodiversity encapsulates only mammals, birds, reptiles and amphibians. We acknowledge the importance of flora and invertebrate inventories when assessing the vulnerability of ecosystems to climate and land-use impacts. We also highlight that SSP5, which operates under RCP8.5, is not the most pessimistic adaptive and migration scenario (see O’Neill et al. ${ }^{38}$ ).

It is also important to note that not all land-use transition will have negative consequences for biodiversity. When cropland, urban areas and managed pasture were considered as a separate multivariate land-use instability metric, the negative correlation between climate velocity and land-use instability increased (Extended Data, Fig. 6, coefficient $=-0.30, p<0.0001$ ). This finding also suggested that regrowth of secondary forests following agricultural abandonment and land management activities may compensate for and enhance a range of ecosystem services across the world. However, given that land-use instability declines towards 2100 (Fig. 1b), land-use transition to natural forms would need to be at a speed comparable to that of the baseline period for restoration and land management efforts towards reversing biodiversity decline to become effective. Nonetheless, further studies aimed at isolating the net transition velocities are required. 
Despite the many complexities and limitations inherent in large-scale studies, our study offers a global quantitative synthesis that shows how climate and land use might interact to influence the dispersal and survival of species in the near term. Our results highlight biogeographic differences and the potential effectiveness of area-based management. Therefore, ambitious climate change mitigation that exploits synergies with land-use systems is required. Anticipating the effects of widespread changes in climate and land use on terrestrial ecosystems is crucial to developing adaptive management systems.

\section{Methods}

Climate and land-use data. We calculated climate velocity for contemporary baseline (1971-2005), near(2015-2050) and far-future (2065-2100) epochs based on mean annual temperature and annual precipitation. Temperature and precipitation data were part of CORDEX of the Coupled Model Intercomparison Projects (CMIP5). We use three global circulation models (GCMs), MOHC-HadGEM2-ES, MPI-M-MPI-ESM-LR and NCC-NorESM1-M. These GCMs, downscaled by the REM02015 regional climate model at $\sim 0.22^{\circ}$ resolution ( $24.42 \mathrm{~km}$ at the Equator), were the only GCMs consistently available across all ten CORDEX regions. Additionally, we used the version one downscaling realisation to reduce inter-model variabilities of velocity estimates. Only the BAU and mitigation scenarios (RCP 8.5 and 2.6, respectively) satisfied these criteria. We constrained our study to latitudes between $60^{\circ} \mathrm{N}$ and $66.5^{\circ} \mathrm{S}$ to account for inconsistent data resolution for Arctic regions. To process CORDEX, we converted monthly climate values to annual mean temperature and total annual precipitation. We refer hereafter to these variables as 'temperature' and 'precipitation' respectively. We chose these variables because of their acknowledged importance in defining climate space for species. ${ }^{3,22}$ Nevertheless, we acknowledge that different climate variables may also facilitate understanding of ecosystem dynamics and global environmental change.

We use the LUH2 datasets; ${ }^{13}$ LUH2 is a new generation of harmonisation that builds upon past work from CMIP5, at higher spatial resolution. For our study, we consider LUH2 v2f, which uses harmonised land-use forcings for 2015-2100. We consider socio-economic pathways, which transitioned continuously from ReMIND-MAgPIE using new CMIP6 future scenarios (RCP-SSP 8.5). LUH2 v2f contains annual states as a percentage of a $0.25 \times 0.25$ degree grid. LUH2 also includes separation of primary forest and secondary natural vegetation into forest and non-forest sub-types, pasture into managed pasture and rangeland, and cropland into multiple crop functional types. Some land-use changes may favour species conservation and potential restoration of natural communities-for example, increases in forest cover. ${ }^{15}$ Therefore, we consider ten land-use states, including cropland, rangeland, managed pasture, primary forest, potentially forested secondary land and urban (Table S4).

To estimate climate velocity, we apply the VoCC in the R statistical computing platform (v4.0.1). ${ }^{39}$ For model runs, VoCC divides a linear slope for each epoch by the spatial gradient. Temperature and precipitation trends were coefficients extracted using simple ordinary least squares (OLS) over 35 years. The spatial gradient is a vector sum of longitudinal and latitudinal pairwise differences in temperature or precipitation at each focal cell using a $3 \times 3$-cell neighbourhood. We averaged velocity estimates between 
GCMs for the same variable within an RCP scenario to produce an ensemble estimate. We applied the same modelling approach to the ten land-use types. Here we use land-use velocity to reflect the degree of instability species may face when relocating to track suitable climate analogues ${ }^{8}$ (hereafter termed landuse instability).

Univariate layers of climate velocity or land-use instability were then combined into multivariate climate and land-use change metrics, following Ordonez et al. ${ }^{15}$ To determine the exposure of conservation areas, we intersected PA polygons from the 2018 World Database on Protected Areas [WDPA] ${ }^{40}$ dataset with raster layers of projected climate velocity and land-use instability. Using a cell centre coverage algorithm, we rasterised the polygons to the grain size of CORDEX. This allowed us to minimise miscalculations that would otherwise be introduced from smaller PAs. This resulted in a set of 9,053 unique PA polygons ( $5.40 \times 10^{6} \mathrm{~km}^{2}$ ). Of these, $\sim 30 \%$ were within IUCN management categories I-II (which we refer to as strict management). We overlaid the PA data with the multivariate climate and land-use instabilities. To examine exposure of global terrestrial protected areas, we merged multivariate metrics into an exposure space bounded by climate velocity and land-use instability. Each axis was scaled relative to the global mean of the contemporary baseline of 1971-2005 to retain pixels that may be high in both epochs.

Next, we examine the relationship between four characteristics of PAs (tetrapod richness, elevation, distance from coasts and IUCN management category) and climate velocity and land-use instability. Systematic monitoring across all important sites (to determine whether the current management regime effectively retains or restores a site's biodiversity value) is required to achieve post-2020 biodiversity conservation objectives. ${ }^{41}$ To this end, we represent relative conservation values of PAs by extracting tetrapods' richness, including birds, amphibians, mammals and reptiles, from Howard, Flather and Stephens. ${ }^{42}$ Thus, we expect the vulnerability of each PA to changes in climate conditions to increase towards PAs which are very important for the conservation of species. ${ }^{4}$ To represent how topographic heterogeneity may become an impediment to migrating species as climate change intensifies, ${ }^{23}$ or may buffer against climate-induced biodiversity loss, we used shuttle radar topography mission's digital elevation model (STRM-DEM). ${ }^{43}$ To examine how a sharp coastal climate gradient might influence potential species migration, we quantified distance from the ocean (see Ackerly et al. ${ }^{22}$ ). Additionally, from the land use and ecological standpoint, projected coastal development by 2100 may increase pressure on protected areas and global conservation goals. Distance from the coast was defined as a Euclidean distance $\left(\mathrm{km}^{2}\right)$ using a boundary shapefile retrieved from GADM v3.4 (www.gadm.org) and implemented in ArcGIS 10.6.1.

\section{Declarations}

Data availability: The authors simulated climate and land-use velocities using VoCC package of $\mathrm{R}$ statistical computing platform v4.0.2. ${ }^{44}$ Model outputs and codes for visualisations are available from the authors upon request. 
Acknowledgement: We thank Di Marco Moreno for providing comments on an earlier version of this work. Asamoah EF acknowledges PhD support from Macquarie University through the International Macquarie Research Excellence Scholarship (iMQRES) program.

\section{References}

1. Watson, J. E. M., Dudley, N., Segan, D. B. \& Hockings, M. The performance and potential of protected areas. Nature 515, 67-73 (2014).

2. Juffe-Bignoli, D. et al. Protected planet report 2014. UNEP-WCMC Cambridge, UK 11, (2014).

3. Elsen, P. R., Monahan, W. B., Dougherty, E. R. \& Merenlender, A. M. Keeping pace with climate change in global terrestrial protected areas. Sci. Adv. 6, eaay0814 (2020).

4. Hoffmann, S., Irl, S. D. H. \& Beierkuhnlein, C. Predicted climate shifts within terrestrial protected areas worldwide. Nat. Commun. 10,1-10 (2019).

5. Batllori, E., Parisien, M. A., Parks, S. A., Moritz, M. A. \& Miller, C. Potential relocation of climatic environments suggests high rates of climate displacement within the North American protection network. Glob. Chang. Biol. 23, 3219-3230 (2017).

6 . Ward, M. et al. Just ten percent of the global terrestrial protected area network is structurally connected via intact land. Nat. Commun. 11, 4563 (2020).

7. Jones, K. R. et al. One-third of global protected land is under intense human pressure. Science (80-). 360, 788-791 (2018).

8. Parks, S. A., Carroll, C., Dobrowski, S. Z. \& Allred, B. W. Human land uses reduce climate connectivity across North America. Glob. Chang. Biol. 26, 2944-2955 (2020).

9. McGuire, J. L., Lawler, J. J., McRae, B. H., Nuñez, T. A. \& Theobald, D. M. Achieving climate connectivity in a fragmented landscape. Proc. Natl. Acad. Sci. 113, 7195-7200 (2016).

10. Watson, J. E. M., Iwamura, T. \& Butt, N. Mapping vulnerability and conservation adaptation strategies under climate change. Nat. Clim. Chang. 3, 989-994 (2013).

11. Pecl, G. T. et al. Biodiversity redistribution under climate change: Impacts on ecosystems and human well-being. Science (80-). 355, eaai9214 (2017).

12. Jones, C., Giorgi, F. \& Asrar, G. The Coordinated Regional Downscaling Experiment: CORDEX-an international downscaling link to CMIP5. CLIVAR Exch. 16, 34-40 (2011).

13. Hurtt, G. C. et al. Harmonization of Global Land-Use Change and Management for the Period 8502100 (LUH2) for CMIP6. Geosci. Model Dev. Discuss. 1-65 (2020). doi:10.5194/GMD-2019-360

14. Loarie, S. R. et al. The velocity of climate change. Nature 462, 1052-1055 (2009).

15. Ordonez, A., Martinuzzi, S., Radeloff, V. C. \& Williams, J. W. Combined speeds of climate and land-use change of the conterminous US until 2050. Nat. Clim. Chang. 4, 811-816 (2014).

16. United Nations. UN General Assembly Resolution A/RES/70/1. (2015). 
17. Harrop, S. R. 'Living in harmony with nature'? Outcomes of the 2010 Nagoya Conference of the Convention on Biological Diversity. J. Environ. Law 23, 117-128 (2011).

18. Maxwell, S. L. et al. Area-based conservation in the twenty-first century. Nature 586, 217-227 (2020).

19. Schwalm, C. R., Glendon, S. \& Duffy, P. B. RCP8.5 tracks cumulative $\mathrm{CO} 2$ emissions. Proc. Natl. Acad. Sci. U. S. A. 117, 19656-19657 (2020).

20. Osorio, F., Vallejos, R. \& Cuevas, F. SpatialPack: Package for analysis of spatial data. $R$ Packag. version 0.2-3, URL CRAN. R-project. org/package = Spat. (2014).

21. Ando, A. W. \& Mallory, M. L. Optimal portfolio design to reduce climate-related conservation uncertainty in the Prairie Pothole Region. Proc. Natl. Acad. Sci. U. S. A. 109, 6484-6489 (2012).

22. Ackerly, D. D. et al. The geography of climate change: implications for conservation biogeography. Divers. Distrib. 16, 476-487 (2010).

23. Dobrowski, S. Z. \& Parks, S. A. Climate change velocity underestimates climate change exposure in mountainous regions. Nat. Commun. 7, 1-8 (2016).

24. Sandel, B. et al. The Influence of Late Quaternary Climate-Change Velocity on Species Endemism. Science (80-). 334, 660-664 (2011).

25. Ordonez, A., Williams, J. W. \& Svenning, J.-C. Mapping climatic mechanisms likely to favour the emergence of novel communities. Nat. Clim. Chang. 6, 1104-1109 (2016).

26. Carroll, C. et al. Scale-dependent complementarity of climatic velocity and environmental diversity for identifying priority areas for conservation under climate change. Glob. Chang. Biol. 23, 4508-4520 (2017).

27. Alexander, J. M. et al. Lags in the response of mountain plant communities to climate change. Glob. Chang. Biol. 24, 563-579 (2018).

28. Lawler, J. J. et al. Projected land-use change impacts on ecosystem services in the United States. Proc. Natl. Acad. Sci. 111, 7492-7497 (2014).

29. Stein, B. A. et al. Preparing for and managing change: climate adaptation for biodiversity and ecosystems. Front. Ecol. Environ. 11, 502-510 (2013).

30. Elsen, P. R., Monahan, W. B. \& Merenlender, A. M. Global patterns of protection of elevational gradients in mountain ranges. Proc. Natl. Acad. Sci. 115, 6004-6009 (2018).

31. Nelson, E. J. et al. Climate change's impact on key ecosystem services and the human well-being they support in the US. Front. Ecol. Environ. 11, 483-893 (2013).

32. Burrows, M. T. et al. The Pace of Shifting Climate in Marine and Terrestrial Ecosystems. Science (80-.). 334, 652-655 (2011).

33. Burrows, M. T. et al. Geographical limits to species-range shifts are suggested by climate velocity. Nature 507, 492-495 (2014).

34. Fitzpatric, M. C., Gove, A. D., Sanders, N. \& Dunn, R. R. Climate change, plant migration, and range collapse in a global biodiversity hotspot: the Banksia (Proteaceae) of Western Australia. Glob. Chang. Biol. 14, 1337-1352 (2008). 
35. Dynesius, M. \& Jansson, R. Evolutionary consequences of changes in species' geographical distributions driven by Milankovitch climate oscillations. Proc. Natl. Acad. Sci. 97, 9115-9120 (2000).

36. Geldmann, J., Manica, A., Burgess, N. D., Coad, L. \& Balmford, A. A global-level assessment of the effectiveness of protected areas at resisting anthropogenic pressures. Proc. Natl. Acad. Sci. 116, 23209-23215 (2019).

37. Tittensor, D. P. et al. Integrating climate adaptation and biodiversity conservation in the global ocean. Sci. Adv. 5, eaay9969 (2019).

38. O'Neill, B. C. et al. The roads ahead: Narratives for shared socioeconomic pathways describing world futures in the 21 st century. Glob. Environ. Chang. 42, 169-180 (2017).

39. Brito-Morales, I. et al. Climate Velocity Can Inform Conservation in a Warming World. Trends Ecol. Evol. 33, 441-457 (2018).

40. UNEP-WCMC \& IUCN. Protected planet: The world database on protected areas (WDPA). (2018).

41. Visconti, P. et al. Protected area targets post-2020. Science (80-.). 364, eaav6886 (2019).

42. Howard, C., Flather, C. H. \& Stephens, P. A. A global assessment of the drivers of threatened terrestrial species richness. Nat. Commun. 11, 993 (2020).

43. Farr, T. G. et al. The shuttle radar topography mission. Rev. Geophys. 45, (2007).

44. García Molinos, J., Schoeman, D. S., Brown, C. J. \& Burrows, M. T. VoCC: An package for calculating the velocity of climate change and related climatic metrics. Methods Ecol. Evol. 10, 2195-2202 (2019).

\section{Figures}




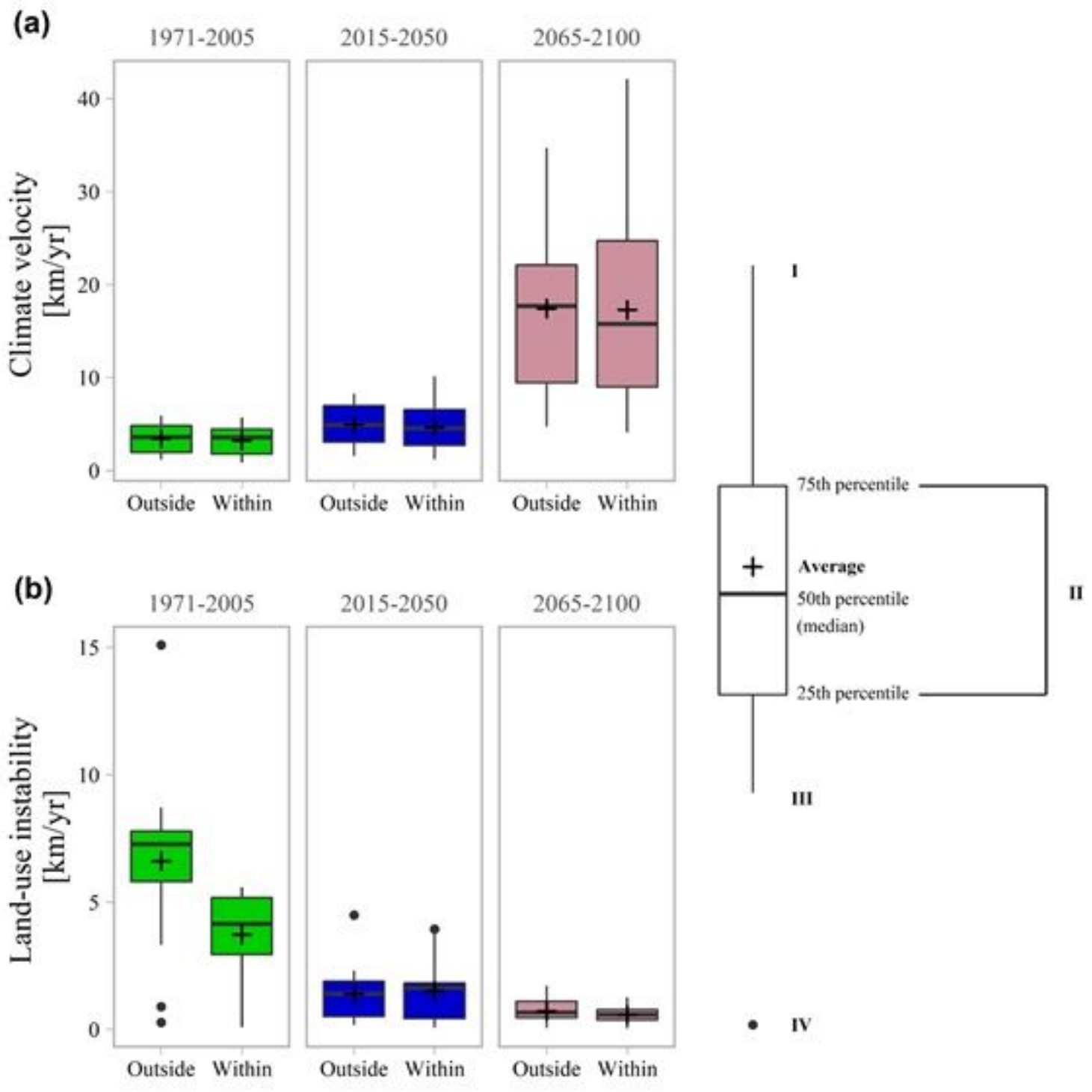

\section{Figure 1}

Spatiotemporal distribution of climate velocity and land-use instability within terrestrial protected areas globally. Estimates for the contemporary to the near-future (2015-2050) and far-future (2065-2100) epochs are based on the business-as-usual climate scenario (Representative Concentration Pathway (RCP) 8.5) and Shared Socioeconomic Pathway (SSP) 5. Boxplot legend abbreviations: (I and III) = largest or smallest value within $1.5 \times$ the interquartile range above 75 th percentile or below 25 th percentile, (II) Interquartile range, and (IV) values greater than 1.5x and less than $3 x$ the interquartile range beyond either end of the box. 
(a)

(b)
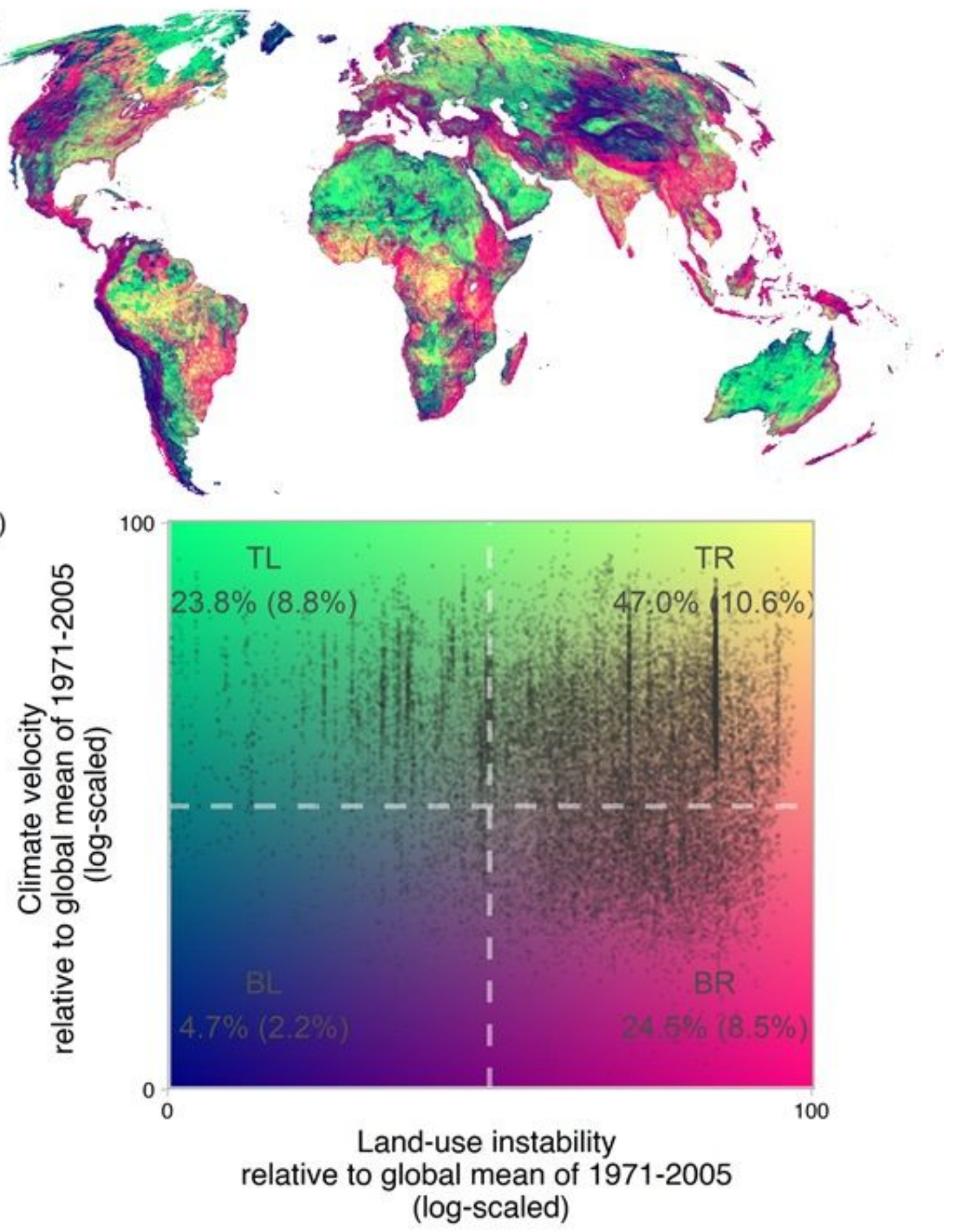

\section{Figure 2}

Global patterns of climate velocity and land-use instability. (a) Bivariate choropleth map of climate velocity and land-use instability showing two-dimensional exposure space across the globe. Both metrics are calculated for the BAU scenario (RCP 8.5) across the contemporary to near future (2015-2050) and presented as changes relative to the global average of the baseline period (1971-2005). (b) Position of terrestrial protected areas (PA) within the climate velocity and land-use instability space. Legend abbreviations: (BL) slow-moving climate and stable land use (blue shades), (TL) fast-moving climate and stable land use (green shades), (TR) fast-moving climate and rapidly-changing land use (yellow shades), 
and (BR) slow-moving climate and rapidly changing land use (red shades). Numbers within brackets of respective quadrants correspond to the proportion by PA pixels within each quadrant for strict IUCN categories. A t-test modified for spatial autocorrelations20 showed a weak negative association between climate velocity and land-use instability within protected areas (coefficient $=-0.22, p<0.0001$ ). Note: The designations employed and the presentation of the material on this map do not imply the expression of any opinion whatsoever on the part of Research Square concerning the legal status of any country, territory, city or area or of its authorities, or concerning the delimitation of its frontiers or boundaries. This map has been provided by the authors.

\section{Supplementary Files}

This is a list of supplementary files associated with this preprint. Click to download.

- ExtendedData.pdf

- Supplementarylnformation.pdf 